\title{
Is Medical Research Informing Professional Practice More Highly Cited? Evidence from AHFS DI Essentials in Drugs.com ${ }^{1}$
}

Mike Thelwall, Kayvan Kousha, Mahshid Abdoli

Statistical Cybermetrics Research Group, School of Mathematics and Computer Science, University of Wolverhampton, Wulfruna Street, Wolverhampton WV1 1LY, UK.

Citation-based indicators are often used to help evaluate the impact of published medical studies, even though the research has the ultimate goal of improving human wellbeing. One direct way of influencing health outcomes is by guiding physicians and other medical professionals about which drugs to prescribe. A high profile source of this guidance is the AHFS DI Essentials product of the American Society of Health-System Pharmacists, which gives systematic information for drug prescribers. AHFS DI Essentials documents, which are also indexed by Drugs.com, include references to academic studies and the referenced work is therefore helping patients by guiding drug prescribing. This article extracts AHFS DI Essentials documents from Drugs.com and assesses whether articles referenced in these information sheets have their value recognised by higher Scopus citation counts. A comparison of mean log-transformed citation counts between articles that are and are not referenced in AHFS DI Essentials shows that AHFS DI Essentials references are more highly cited than average for the publishing journal. This suggests that medical research influencing drug prescribing is more cited than average.

\section{Introduction}

Citation counts are important in medical fields to help research evaluation. In the UK Research Excellence Framework (REF) 2014, although only 11 of the 36 disciplinary areas into which all research was categorised drew upon citation counts, these 11 included Clinical Medicine and the two other health fields (Wilsdon, Allen, Belfiore, Campbell, Curry, et al. 2015). Citations counts and related indicators, such as Journal Impact Factors and the $\mathrm{h}$ index, may also be used in appointments, promotion, tenure and funding decisions (e.g., Curry, 2012; Feder \& Madara, 2008), although various bodies have outlawed some or all of these (Schekman \& Patterson, 2013). Citation counts have well-known limitations because they do not directly measure research value. In particular, applied research can be useful for non-academics that do not cite it and so can be undervalued by traditional citation counts (e.g., biomedical research: Lewison, \& Dawson, 1998). It is therefore important to seek other indicators for different types of research value (Priem, Taraborelli, Groth, \& Neylon, 2010) including in the medical sciences (Barbic, Tubman, Lam, \& Barbic, 2016; Scarlat, Mavrogenis, Pećina, \& Niculescu, M, 2015). One way in which medical research can be useful is by influencing medicine prescribing by clinicians. Although previous studies have shown that it is possible to get evidence of clinical impact from citations in UK health professional guidelines (Grant, 1999; Grant, Cottrell, Cluzeau, \& Fawcett, 2000; Kryl, Allen, Dolby, Sherbon, \& Viney, 2012; Lewison \& Sullivan, 2008; Thelwall \& Maflahi, 2016) and indirectly from mainly U.S.-based clinical trials (Thelwall \& Kousha, 2016), additional sources

\footnotetext{
${ }^{1}$ Thelwall, M., Kousha, K. \& Abdoli, M. (in press). Is medical research informing professional practice more highly cited? Evidence from AHFS DI Essentials in Drugs.com. Scientometrics. doi:10.1007/s11192-017-2292-3
} 
of evidence are needed for a more complete picture, including for the key step of drug prescribing.

In the biomedical field, citations in various forms are widely used in research evaluation. These include simple citation counts, Journal Impact Factors (JIFs) and the hindex, despite the acknowledged limitations of all of these. The importance of using some form of citation analysis for biomedical research has been implicitly acknowledge by the creation of a new indicator, The Relative Citation Ratio (RCR), by the Office of Portfolio Analysis, National Institutes of Health (Hutchins, Yuan, Anderson, Santangelo, 2016). The purpose of the RCR was to overcome many of the limitations of other indicators through the use of a complex algorithm to minimise the risk that articles are unfairly treated in citation comparisons. Nevertheless, citation-based algorithms cannot measure the clinical value of research. It role is to support rather than replace expert judgements.

The American Society of Health-System Pharmacists (ASHP) is a professional association to provide support for, and advocacy on behalf of, pharmacists in hospitals and other parts of the health system in the U.S.A. It that produces, amongst other things, "an evidence-based foundation for safe and effective drug therapy" (www.ashp.org/menu/AboutUs/WhatWeDo). Its key product for practitioners is AHFS DI Essentials, which gives a range of information about drugs to inform decisions about whether to prescribe them and how to identify problems with patients taking them. This appears to be an independent evidence-based source of drug information because ASHP publishes clear guidelines for this (http://www.ahfsdruginformation.com/editorialindependence/). Each medication has a self-contained document (called a monograph) that is underpinned by traditional academic references through a reference list at the end. The documents are intended to support prescribing in the U.S.A. but, through their hosting on the website drugs.com, also reach an international audience. Drugs.com was the most popular pharmacy website in the world, according to Alexa.com in December 2016 (http://www.alexa.com/topsites/category/Top/Health/Pharmacy), with half (48.5\%) of its visitors originating from the U.S.A., but India, the UK, Canada and Australia also having substantial numbers of users (http://www.alexa.com/siteinfo/drugs.com).

Because of its authoritative origins and the presence of references, AHFS DI Essentials is a suitable new source of evidence about scholarly articles that have had an impact on prescribing practices. In contrast to the free online UK NICE Guidelines (Thelwall \& Maflahi, 2016), it focuses on drugs rather than illnesses, and is not an official national source of information. Nevertheless, its extensive and focused collection of medical references is potentially useful as applied medical impact evidence. There are other similar national sources of drug information, such as the British National Formulary (BNF) pharmaceutical reference book from the UK's Royal Pharmaceutical Society and British Medical Association, and Martindale: The Complete Drug Reference from the UK's Royal Pharmaceutical Society publishing house, but AHFS DI Essentials seems to be authoritative and one of the few that is free online.

\section{Research questions}

Articles referenced in AHFS DI Essentials apparently have a direct impact on prescribing practice in the U.S.A. and therefore successfully achieve the main goal of medical research: improving health outcomes. Nevertheless, the authors of the referenced articles are likely to be evaluated by the publishing venue (the perceived value of the journal) or their citation counts in the form of a h-index or a total citation count. If articles referenced in AHFS DI 
Essentials tend not to be highly cited, then the contributions of their authors would be undervalued in research evaluations. This is possible because basic medical research attracts citations from both basic and applied research, whereas applied research attracts few basic citations in medicine (Narin, Pinski, \& Gee, 1976). Hence the main research question is to check whether the traditional research evaluation source of quantitative evidence, academic citations, undervalues AHFS DI Essentials references.

- Are articles referenced in AHFS DI Essentials less cited than average?

\section{Methods}

The overall research design was to extract all references from AHFS DI Essentials, identify the most cited journals, and compare the citation counts of the AHFS DI Essentials references in these journals with the remaining articles to see if they tend to be more cited. Although a more standard approach would be to compare papers within individual Scopus or Web of Science fields rather than within individual journals, a journal-based approach is preferable for greater specificity. In particular, several important medical journals are generalist (e.g., NEJM, Lancet, JAMA) and therefore not amenable to fine-grained field categorisation. In contrast, a focus on journals allows the finest grained classification possible (at least for any journal-based classification scheme, c.f.: Small, Sweeney, \& Greenlee, 1985) without the possibility that the results are tainted by inappropriate or multiple journal classifications. Another advantage is that medical professionals may focus on specific high impact journals (as claimed by: Goldacre, 2009), which may distort the relationship between the value of an article and the number of times it is cited, undermining field-wide analyses. Two disadvantages of a focus on journals are reduced statistical power from fewer articles to analyse in each individual test and reduced statistical power from losing the differentiation between higher and lower average quality journals in the same field. Moreover, industry-funded research may tend to be published in higher impact, more general journals (Jefferson, Di Pietrantonj, Debalini, Rivetti, \& Demicheli, 2009b) which will affect the results to some extent, although this would also be true for a field-based classification scheme if industry articles received a citation boost from their presence in higher impact journals.

Although AHFS DI Essentials references include books, reviews, meta-analyses, and other documents the analysis here focuses on standard journal articles because these are the primary vehicle for publishing original research and therefore the most important type of cited document from a research evaluation perspective.

The AHFS DI Essentials documents are not publically available from the originating organisation's website and so they were accessed from Drugs.com instead. The Drugs.com sitemap (https://www.drugs.com/sitemap_index.xml.gz) was used to identify the 2417 AHFS DI Essentials pages in the site (with URLS starting with https://www.drugs.com/monograph/) and these were downloaded using the free web crawler SocSciBot (socscibot.wlv.ac.uk) on 21 October 2016, using a slow ethical crawl (Thelwall \& Stuart, 2006). The references on these pages were extracted using a program added to the free software Webometric Analyst (lexiurl.wlv.ac.uk: Drugs.com: Extract references in the Services menu). The metadata from articles in the ten most cited journals identified in the reference lists was then downloaded from the Scopus website in November 2016, covering the 21 years from 1996 (when Scopus expanded its coverage) to 2016. Only documents of Scopus type Journal Article, excluding reviews, were downloaded. One of the journals, Drugs, had few articles in recent years (most were classified by Scopus as other 
document types) and so the $11^{\text {th }}$ journal largest was also downloaded as an addition. Scopus was chosen in preference to the Web of Science for its greater coverage of the literature, with the latter essentially forming a subset of the former (Archambault, Campbell, Gingras, \& Larivière, 2009; Moed \& Visser, 2008).

The next stage was to match the AHFS DI Essentials references with the Scopus articles for the 11 journals. Although the AHFS DI Essentials references were reasonably standardised, they did not include DOIs, used abbreviated journal names and included many nonstandard documents, making the matching process not straightforward. To ensure accuracy, articles were matched based on PubMed IDs, ignoring articles in AHFS DI Essentials and Scopus without PubMed IDs. Thus, for each journal, two lists of articles were created: one with PubMed IDs and matching a AHFS DI Essentials PubMed ID, and one with PubMed IDs but no matching AHFS DI Essentials PubMed ID. Articles from journals in years with no AHFS DI Essentials references were discarded as unnecessary for the subsequent indicator calculations.

For each journal, the year-normalised average citation count of articles referenced by AHFS DI Essentials was calculated by comparing it to the remaining articles in the journal. The Mean Normalised Log Citation Score (MNLCS) was used for this (Thelwall, 2017). This calculation is appropriate for individual academic journals because their citations tend to be highly skewed (de Solla Price, 1976), following hooked power law distribution (Thelwall, 2016a) and the MNLCS incorporates a logarithmic transformation to eliminate this skewing. MNLCS is preferable to MNCS (Waltman, van Eck, van Leeuwen, Visser, \& van Raan, 2011ab) because of the skewed nature of citation counts, an issue that is also not dealt with by the Relative Citation Ratio (RCR) (Hutchins, Yuan, Anderson, Santangelo, 2016).

For each AHFS DI Essentials article $d$, its citation count $c_{d}$ is replaced by $\ln (1+$ $\left.c_{d}\right) / y\left(c_{d}\right)$ where $y\left(c_{d}\right)$ is the arithmetic mean of the $\ln (1+c)$ values for all articles published in the same journal and year as $d$, excluding the matching AHFS DI Essentials articles (to increase statistical power). The MNLCS value for the journal is then the arithmetic mean of all the adjusted citation counts $\ln \left(1+c_{d}\right) / y\left(c_{d}\right)$. This calculation is not biased against newer articles because the citation count of each article is normalised against other articles from the same year. Although this gives an advantage to articles published earlier in the year, this should not introduce a source of systematic bias for or against AHFS DI Essentials references. Confidence intervals were calculated using Fieller's (1954) formula for the ratio of two normal distributions, which is a conservative approach because it treats the journal citation average as an estimate rather than a precise value (see also: Thelwall, 2017, in press).

\section{Results}

For each journal, the year-normalised average number of citations per article is higher than the journal average, and the difference is statistically significant in all cases (Table 1). Surprisingly, the highest impact general medical journals are at the top of the list and the difference between individual journals is statistically significant for the top journals (as a rule of thumb, if the confidence intervals do not overlap or only overlap a little then the difference is statistically significant). Additional investigations, as described below, were conducted to explore and check the results. 
Table 1. Year-normalised average log citations (MNLCS) for articles referenced by AHFS DI Essentials references for the 11 journals with the most articles. Journals are ordered by MNLCS.

\begin{tabular}{|l|r|r|r|r|r|r|}
\hline & $\begin{array}{l}\text { AHFS- } \\
\text { cited } \\
\text { articles }\end{array}$ & MNLCS (95\% Cl) & $\begin{array}{l}\text { Journal } \\
\text { articles }\end{array}$ & $\begin{array}{l}\text { First } \\
\text { year }\end{array}$ & $\begin{array}{l}\text { Last } \\
\text { year }\end{array}$ & Years \\
\hline The Lancet & 336 & $1.89(1.84,1.94)$ & 11749 & 1996 & 2015 & 20 \\
\hline JAMA & 171 & $1.58(1.51,1.65)$ & 5897 & 1996 & 2016 & 19 \\
\hline New England Journal of Medicine & 613 & $1.47(1.45,1.49)$ & 6064 & 1996 & 2015 & 20 \\
\hline Circulation & 114 & $1.36(1.32,1.41)$ & 14270 & 1996 & 2015 & 20 \\
\hline BMJ & 36 & $1.36(1.23,1.48)$ & 5230 & 1996 & 2012 & 16 \\
\hline Journal of Clinical Oncology & 377 & $1.31(1.29,1.34)$ & 10360 & 1996 & 2015 & 20 \\
\hline Clinical Infectious Diseases & 201 & $1.29(1.25,1.33)$ & 8307 & 1996 & 2016 & 21 \\
\hline $\begin{array}{l}\text { Archives of Internal Medicine/ } \\
\text { JAMA Internal Medicine }\end{array}$ & 50 & $1.19(1.12,1.25)$ & 3542 & 1996 & 2013 & 13 \\
\hline $\begin{array}{l}\text { Antimicrobial Agents \& } \\
\text { Chemotherapy }\end{array}$ & 364 & $1.18(1.15,1.21)$ & 13533 & 1996 & 2015 & 20 \\
\hline Pediatrics & 54 & $1.16(1.08,1.23)$ & 7022 & 1996 & 2015 & 16 \\
\hline Drugs & 56 & $1.12(1.05,1.19)$ & 417 & 1996 & 2015 & 12 \\
\hline
\end{tabular}

Despite the overall average citation advantage, individual articles referenced by AHFS DI Essentials may still be less cited than average for the publishing journal. For example, 14 of the 336 in the top journal in Table 1, The Lancet, had below average citation counts. An examination of these found many that were not standard research articles (Table 2), explaining this. Nevertheless, the prevalence of non-articles within the Lancet Scopus results suggests that the high MNLCS values for AHFS-cited articles in The Lancet in Table 1 may be at least partly due to the presence of non-article document types classified as articles in Scopus within the remainder of the journal (additional manual checks found similar classification errors in some of the remaining articles in this journal). Similar problems occurred in eight of the remaining ten journals (see Appendix and Table 3). 
Table 2. All articles referenced by AHFS DI Essentials but attracting fewer citations than average for The Lancet.

\begin{tabular}{|c|c|c|c|c|}
\hline Year & $\begin{array}{l}\text { Scopus } \\
\text { citations }\end{array}$ & $\begin{array}{l}\text { Norm. } \\
\text { cit. }\end{array}$ & Article & $\begin{array}{l}\text { Type in journal } \\
\text { website }\end{array}$ \\
\hline 1998 & 0 & 0.00 & $\begin{array}{l}\text { WHO launches cautiously optimistic report on } \\
\text { health }\end{array}$ & News \\
\hline 2008 & 2 & 0.36 & $\begin{array}{l}\text { Timeframe for thrombolysis in acute ischaemic } \\
\text { stroke }\end{array}$ & Comment \\
\hline 1996 & 4 & 0.54 & Treatment of Kawasaki disease & Commentary \\
\hline 1997 & 8 & 0.68 & $\begin{array}{l}\text { Acute pancreatitis during treatment with } \\
\text { amiodarone }\end{array}$ & Research Letter \\
\hline 1999 & 12 & 0.83 & Hypercalcaemia in sarcoidosis & Case Report \\
\hline 1998 & 9 & 0.84 & Raloxifene-associated hepatitis & Research Letter \\
\hline 1998 & 10 & 0.87 & Experts argue about tamoxifen prevention trial & News \\
\hline 1997 & 16 & 0.88 & $\begin{array}{l}\text { Aberrant atrioventricular conduction triggered by } \\
\text { antimalarial prophylaxis with mefloquine }\end{array}$ & Research Letter \\
\hline 2011 & 33 & 0.90 & Spider bite & Seminar \\
\hline 1997 & 19 & 0.93 & $\begin{array}{l}\text { Fatal toxic epidermal necrolysis associated with } \\
\text { mefloquine antimalarial prophylaxis }\end{array}$ & Research Letter \\
\hline 2000 & 19 & 0.96 & $\begin{array}{l}\text { Pharmacological implications of lengthened in- } \\
\text { utero exposure to nevirapine }\end{array}$ & Research Letter \\
\hline 2005 & 33 & 0.99 & $\begin{array}{l}\text { Single-dose ciprofloxacin versus 12-dose } \\
\text { erythromycin for childhood cholera: A randomised } \\
\text { controlled trial }\end{array}$ & Article \\
\hline 2010 & 23 & 0.99 & $\begin{array}{l}\text { Alteplase for ischaemic stroke-much sooner is } \\
\text { much better }\end{array}$ & Comment \\
\hline 2012 & 60 & 0.99 & $\begin{array}{l}\text { Efficacy and safety of an extended nevirapine } \\
\text { regimen in infant children of breastfeeding } \\
\text { mothers with HIV-1 infection for prevention }\end{array}$ & Article \\
\hline
\end{tabular}

The second journal in Table, 1, JAMA, also has papers classified as articles in Scopus that are classified as something else in the JAMA website (Table 3 ). In addition, some JAMA papers that were classified as articles in Scopus and in the JAMA website were not classical journal articles. For example, Typhoid fever (http://jamanetwork.com/journals/jama/articleabstract/418141) has a subtitle Case Presentation and starts, "A 35-year-old Maryland woman came to her local hospital on December 4, 1994, complaining of fever and chills for 1 week." This is clearly not a traditional medical journal article. Similarly, the two different articles with the same title, "From the Food and Drug Administration" (http://jamanetwork.com/journals/jama/articleabstract/418112 and http://jamanetwork.com/journals/jama/article-abstract/415730) are news stories even though they are both labelled "Article" by JAMA and Scopus. The first one has subtitle State Contracts for Enforcement of FDA Tobacco Regulations and starts, "The FDA is contracting with states throughout the country to help enforce requirements of the new tobacco regulation to protect children and adolescents." Hence the problem here is the non-standard labelling of outputs by JAMA and copying by Scopus. 
Table 3. All articles referenced by AHFS DI Essentials but attracting fewer citations than average for JAMA.

\begin{tabular}{|c|c|c|c|c|}
\hline Year & $\begin{array}{l}\text { Scopus } \\
\text { citations }\end{array}$ & $\begin{array}{l}\text { Norm. } \\
\text { cit. }\end{array}$ & Article & $\begin{array}{l}\text { Type in journal } \\
\text { website }\end{array}$ \\
\hline 1997 & 0 & 0.00 & From the Food and Drug Administration. & Article \\
\hline 1997 & 1 & 0.21 & From the Food and Drug Administration. & Article \\
\hline 2005 & 37 & 0.71 & $\begin{array}{l}\text { Life-threatening sepsis associated with } \\
\text { adjuvant doxorubicin plus docetaxel for } \\
\text { intermediate-risk breast cancer }\end{array}$ & Brief Report \\
\hline 2008 & 42 & 0.76 & $\begin{array}{l}\text { Comparison of annual and biannual mass } \\
\text { antibiotic administration for elimination of } \\
\text { infectious trachoma }\end{array}$ & Article \\
\hline 2005 & 55 & 0.78 & $\begin{array}{l}\text { Multidrug resistance among persons with } \\
\text { tuberculosis in California, 1994-2003 }\end{array}$ & Article \\
\hline 2007 & 60 & 0.81 & Adult cystic fibrosis & $\begin{array}{l}\text { Grand Rounds/ } \\
\text { | Clinician's } \\
\text { Corner }\end{array}$ \\
\hline 2006 & 71 & 0.81 & $\begin{array}{l}\text { Effect of a single mass antibiotic distribution } \\
\text { on the prevalence of infectious trachoma }\end{array}$ & Article \\
\hline 2006 & 77 & 0.83 & $\begin{array}{l}\text { Botulism in } 4 \text { adults following cosmetic } \\
\text { injections with an unlicensed, highly } \\
\text { concentrated botulinum preparation }\end{array}$ & Brief Report \\
\hline 2004 & 81 & 0.85 & $\begin{array}{l}\text { Growth hormone - Releasing hormone in HIV- } \\
\text { infected men with lipodystrophy: A } \\
\text { randomized controlled trial }\end{array}$ & $\begin{array}{l}\text { Preliminary } \\
\text { Communication }\end{array}$ \\
\hline 2010 & 55 & 0.85 & $\begin{array}{l}\text { Atypical fractures as a potential complication } \\
\text { of long-term bisphosphonate therapy }\end{array}$ & $\begin{array}{l}\text { Grand Rounds/ } \\
\text { Clinician's } \\
\text { Corner }\end{array}$ \\
\hline 1997 & 16 & 0.86 & Typhoid fever & Article \\
\hline 1996 & 17 & 0.88 & $\begin{array}{l}\text { Importance of Surrogate Markers in } \\
\text { Evaluation of Antiviral Therapy for HIV } \\
\text { Infection }\end{array}$ & Article \\
\hline 1996 & 23 & 0.97 & $\begin{array}{l}\text { Antibody response to measles-mumps-rubella } \\
\text { vaccine of children with mild illness at the } \\
\text { time of vaccination }\end{array}$ & Article \\
\hline 2008 & 124 & 0.98 & $\begin{array}{l}\text { Sildenafil treatment of women with } \\
\text { antidepressant-associated sexual dysfunction: } \\
\text { A randomized controlled trial }\end{array}$ & Article \\
\hline
\end{tabular}

Antimicrobial Agents \& Chemotherapy (Table 4) and the Journal of Clinical Oncology (Table 5) do not seem to have non-standard article types classified as articles in Scopus, as confirmed by additional random checks on low cited articles. Thus, these journals give the clearest evidence that articles referenced by AHFS DI Essentials are more highly cited than comparable articles from the same journal. The list sin Tables 4 and 5 also gives concrete evidence that articles useful enough to be references in AHFS DI Essentials do not necessarily attract many Scopus citations. 
Table 4. Top 20 articles referenced by AHFS DI Essentials but attracting fewer citations than average for Journal of Clinical Oncology.

\begin{tabular}{|c|c|c|c|c|}
\hline Year & $\begin{array}{l}\text { Scopus } \\
\text { citations }\end{array}$ & $\begin{array}{l}\text { Norm. } \\
\text { cit. }\end{array}$ & Article & $\begin{array}{l}\text { Type in } \\
\text { journal } \\
\text { website }\end{array}$ \\
\hline 2002 & 17 & 0.64 & $\begin{array}{l}\text { Phase I clinical and pharmacologic trial of intravenous } \\
\text { estramustine phosphate }\end{array}$ & Article \\
\hline 1998 & 19 & 0.68 & $\begin{array}{l}\text { Combination of consecutive low-dose cisplatin with } \\
\text { bleomycin, vincristine, and mitomycin for recurrent cervical } \\
\text { carcinoma }\end{array}$ & Article \\
\hline 2008 & 17 & 0.71 & $\begin{array}{l}\text { Fatal toxic epidermal necrolysis associated with cetuximab } \\
\text { in a patient with colon cancer }\end{array}$ & Article \\
\hline 1998 & 28 & 0.76 & $\begin{array}{l}\text { Phase III randomized trial comparing cisplatin and } \\
\text { carboplatin with or without ifosfamide in patients with } \\
\text { advanced non-small-cell lung cancer }\end{array}$ & Article \\
\hline 1998 & 32 & 0.79 & $\begin{array}{l}\text { Ninety-six-hour infusional paclitaxel as salvage therapy of } \\
\text { ovarian cancer patients previously failing treatment with 3- } \\
\text { hour or 24-hour paclitaxel infusion regimens }\end{array}$ & Article \\
\hline 1996 & 32 & 0.79 & $\begin{array}{l}\text { Paclitaxel in combination chemotherapy with radiotherapy } \\
\text { in patients with unresectable stage III non-small-cell lung } \\
\text { cancer }\end{array}$ & Article \\
\hline 2005 & 34 & 0.81 & $\begin{array}{l}\text { Study of paclitaxel, etoposide, and cisplatin chemotherapy } \\
\text { combined with twice-daily thoracic radiotherapy for } \\
\text { patients with limited-stage small-cell lung cancer: A } \\
\text { Radiation Therapy Oncology Group } 9609 \text { phase II study }\end{array}$ & Article \\
\hline 2005 & 35 & 0.82 & $\begin{array}{l}\text { Side effects related to cancer treatment: Case } 2 \text {. Splenic } \\
\text { rupture following pegfilgrastim }\end{array}$ & Article \\
\hline 1996 & 38 & 0.83 & $\begin{array}{l}\text { Phase I and pharmacologic study of high doses of the } \\
\text { topoisomerase I inhibitor topotecan with granulocyte } \\
\text { colony-stimulating factor in patients with solid tumors }\end{array}$ & Article \\
\hline 1998 & 42 & 0.85 & $\begin{array}{l}\text { Phase II study of carmustine, dacarbazine, cisplatin, and } \\
\text { tamoxifen in advanced melanoma: A southwest oncology } \\
\text { group study }\end{array}$ & Article \\
\hline 1997 & 37 & 0.86 & $\begin{array}{l}\text { Neurotoxicity and ototoxicity of cisplatin plus paclitaxel in } \\
\text { comparison to cisplatin plus cyclophosphamide in patients } \\
\text { with epithelial ovarian cancer }\end{array}$ & Article \\
\hline 2000 & 44 & 0.86 & $\begin{array}{l}\text { Phase I and pharmacokinetic study of a new taxoid, RPR } \\
109881 \mathrm{~A} \text {, given as a 1-hour intravenous infusion in patients } \\
\text { with advanced solid tumors }\end{array}$ & Article \\
\hline 1997 & 38 & 0.86 & $\begin{array}{l}\text { Fluorouracil plus racemic leucovorin versus fluorouracil } \\
\text { combined with the pure l-isomer of leucovorin for the } \\
\text { treatment of advanced colorectal cancer: A randomized } \\
\text { phase III study }\end{array}$ & Article \\
\hline 1997 & 41 & 0.88 & $\begin{array}{l}\text { Prospectively randomized north central cancer treatment } \\
\text { group trial of intensive-course fluorouracil combined with } \\
\text { the l-isomer of intravenous leucovorin, oral leucovorin, or } \\
\text { intravenous leucovorin for the treatment of advanced } \\
\text { colorectal cancer }\end{array}$ & Article \\
\hline 1997 & 41 & 0.88 & $\begin{array}{l}\text { Phase II randomized trial of gallium nitrate plus fluorouracil } \\
\text { versus methotrexate, vinblastine, doxorubicin, and cisplatin } \\
\text { in patients with advanced transitional-cell carcinoma }\end{array}$ & Article \\
\hline
\end{tabular}




\begin{tabular}{|l|r|r|l|l|}
\hline 1999 & 47 & 0.88 & $\begin{array}{l}\text { Cisplatin, etoposide, and paclitaxel in the treatment of } \\
\text { patients with extensive small-cell lung carcinoma }\end{array}$ & Article \\
\hline 2007 & 36 & 0.88 & Bevacizumab 5 mg/kg can be infused safely over 10 minutes & Article \\
\hline 1997 & 45 & 0.90 & $\begin{array}{l}\text { Rapid recovery of spermatogenesis after mitoxantrone, } \\
\text { vincristine, vinblastine, and prednisone chemotherapy for } \\
\text { Hodgkin's disease }\end{array}$ & Article \\
\hline 1999 & 56 & 0.92 & $\begin{array}{l}\text { Phase I and pharmacologic study of the tyrosine kinase } \\
\text { inhibitor SU101 in patients with advanced solid tumors }\end{array}$ & Article \\
\hline 1998 & 60 & 0.93 & $\begin{array}{l}\text { Multicenter phase Il trial of interleukin-2, interferon- } \alpha \text {, and } \\
\text { 13-cis- retinoic acid in patients with metastatic renal-cell } \\
\text { carcinoma }\end{array}$ & Article \\
\hline
\end{tabular}

Table 5. The top 20 articles referenced by AHFS DI Essentials but attracting fewer citations than average for Antimicrobial Agents \& Chemotherapy.

\begin{tabular}{|c|c|c|c|c|}
\hline Year & $\begin{array}{l}\text { Scopus } \\
\text { citations }\end{array}$ & $\begin{array}{l}\text { Norm. } \\
\text { cit. }\end{array}$ & Article & $\begin{array}{l}\text { Type in } \\
\text { journal } \\
\text { website }\end{array}$ \\
\hline 1997 & 0 & 0.00 & $\begin{array}{l}\text { Pharmacokinetic interaction of megestrol acetate with } \\
\text { zidovudine in human immunodeficiency virus-infected } \\
\text { patients }\end{array}$ & Article \\
\hline 2000 & 5 & 0.48 & $\begin{array}{l}\text { Bioavailability of once- and twice-daily regimens of } \\
\text { didanosine in human immunodeficiency virus-infected } \\
\text { children }\end{array}$ & Article \\
\hline 1996 & 5 & 0.53 & Penetration of ceftibuten into middle ear fluid & Article \\
\hline 2011 & 4 & 0.55 & $\begin{array}{l}\text { Concentrations of tenofovir and emtricitabine in saliva: } \\
\text { Implications for preexposure prophylaxis of oral HIV } \\
\text { acquisition }\end{array}$ & Article \\
\hline 1996 & 6 & 0.58 & $\begin{array}{l}\text { Lack of effect of concomitant zidovudine on rifabutin } \\
\text { kinetics in patients with AIDS-related complex }\end{array}$ & Article \\
\hline 1996 & 6 & 0.58 & $\begin{array}{l}\text { Penetration of ceftriaxone ( } 1 \text { or } 2 \text { grams intravenously) } \\
\text { into mediastinal and cardiac tissues in humans }\end{array}$ & Article \\
\hline 1996 & 7 & 0.62 & $\begin{array}{l}\text { Absence of effect of trimethoprim-sulfamethoxazole on } \\
\text { pharmacokinetics of zidovudine in patients infected with } \\
\text { human immunodeficiency virus }\end{array}$ & Article \\
\hline 2006 & 8 & 0.63 & $\begin{array}{l}\text { Dose separation does not overcome the pharmacokinetic } \\
\text { interaction between fosamprenavir and lopinavir/ritonavir }\end{array}$ & Article \\
\hline 1997 & 9 & 0.64 & $\begin{array}{l}\text { Rifabutin absorption in the gut unaltered by concomitant } \\
\text { administration of didanosine in AIDS patients }\end{array}$ & Article \\
\hline 1999 & 10 & 0.65 & $\begin{array}{l}\text { A multiple drug interaction study of stavudine with agents } \\
\text { for opportunistic infections in human immunodeficiency } \\
\text { virus-infected patients }\end{array}$ & Article \\
\hline 2011 & 6 & 0.67 & $\begin{array}{l}\text { Nelfinavir and its active metabolite, hydroxy-t- } \\
\text { butylamidenelfinavir (M8), are transferred in small } \\
\text { quantities to breast milk and do not reach biologically } \\
\text { significant concentrations in breast-feeding infants whose } \\
\text { mothers are taking nelfinavir }\end{array}$ & Article \\
\hline 1996 & 9 & 0.68 & $\begin{array}{l}\text { Investigation of bioequivalence and tolerability of } \\
\text { intramuscular ceftriaxone injections by using } 1 \% \text { lidocaine, } \\
\text { buffered lidocaine, and sterile water diluents }\end{array}$ & Article \\
\hline 2014 & 3 & 0.70 & EUCAST testing of isavuconazole susceptibility in & Article \\
\hline
\end{tabular}




\begin{tabular}{|l|r|r|l|l|}
\hline & & & $\begin{array}{l}\text { Aspergillus: Comparison of results for inoculum } \\
\text { standardization using conidium counting versus optical } \\
\text { density }\end{array}$ & \\
\hline 2014 & 3 & 0.70 & $\begin{array}{l}\text { Avibactam and class C } \beta \text {-lactamases: Mechanism of } \\
\text { inhibition, conservation of the binding pocket, and } \\
\text { implications for resistance }\end{array}$ & Article \\
\hline 2011 & 7 & 0.71 & $\begin{array}{l}\text { In vitro efficacy of antibiotics commonly used to treat } \\
\text { human plague against intracellular Yersinia pestis }\end{array}$ & Article \\
\hline 2011 & 7 & 0.71 & $\begin{array}{l}\text { Pharmacokinetic interaction study of ritonavir-boosted } \\
\text { saquinavir in combination with rifabutin in healthy } \\
\text { subjects }\end{array}$ & Article \\
\hline 1997 & 13 & 0.73 & $\begin{array}{l}\text { Pharmacokinetic study of cefodizime and ceftriaxone in } \\
\text { sera and bones of patients undergoing hip arthroplasty }\end{array}$ & Article \\
\hline 2002 & 13 & 0.73 & $\begin{array}{l}\text { Penciclovir susceptibilities of herpes simplex virus isolates } \\
\text { from patients using penciclovir cream for treatment of } \\
\text { recurrent herpes labialis }\end{array}$ & Article \\
\hline 1997 & 14 & 0.75 & $\begin{array}{l}\text { Effect of fluconazole on the steady-state pharmacokinetics } \\
\text { of delavirdine in human immunodeficiency virus-positive } \\
\text { patients }\end{array}$ & Article \\
\hline 2007 & 12 & 0.76 & $\begin{array}{l}\text { Diminished ciprofloxacin-induced chondrotoxicity by } \\
\text { supplementation with magnesium and vitamin E in } \\
\text { immature rats }\end{array}$ & Article \\
\hline
\end{tabular}

The higher average citation impact of articles in or Journal of Clinical Oncology and Antimicrobial Agents \& Chemotherapy that are referenced by AHFS DI Essentials could be due to changes in classification practices in the journals over time or miss-classifications for a single issue, but this can be checked for by monitoring the results over time. Since the citation impact of articles referenced in AHFS DI Essentials is above the world average in every year (Figures 1 and 2), it is clear that isolated misclassifications or changes over time cannot explain the impact difference. To further check this, the smallest set of world articles from a single year was investigated in more detail, the 204 articles from 2015 in Antimicrobial Agents \& Chemotherapy. All of these were correctly classified as articles, confirming that misclassifications are not a problem for this journal. The shortest article had only two pages (In vitro susceptibility testing of eravacycline is unaffected by medium age and nonstandard assay parameters) but these are labelled in the same way as long form articles and are clearly genuine research articles. This journal allows authors to submit short articles, but both are given equally rigorous reviewing and so it seems reasonable to regard them as equivalent, "The Short-Form format is intended for the presentation of brief observations that do not warrant full-length papers. Submit Short-Form papers in the same way as full-length papers. They receive the same review, they are not published more rapidly than full-length papers, and they are not considered preliminary communications." (http://aac.asm.org/site/misc/journal-ita org.xhtml\#05). Nevertheless, longer articles tend to be slightly more cited (Pearson correlation 0.220 between page length and the natural log of citation counts plus one) and so it is possible that they are more valuable overall. This cannot explain the AHFS DI Essentials references advantage, however, since in 2015 they cite papers with average length 5.2 pages, whereas the journal average for the year was 6.3. Thus, the finding for Antimicrobial Agents \& Chemotherapy in 2015 is not due to different article types (because there aren't any) or lengths (because AHFS DI Essentials references cite shorter papers but longer papers in the journal tend to be more cited). 


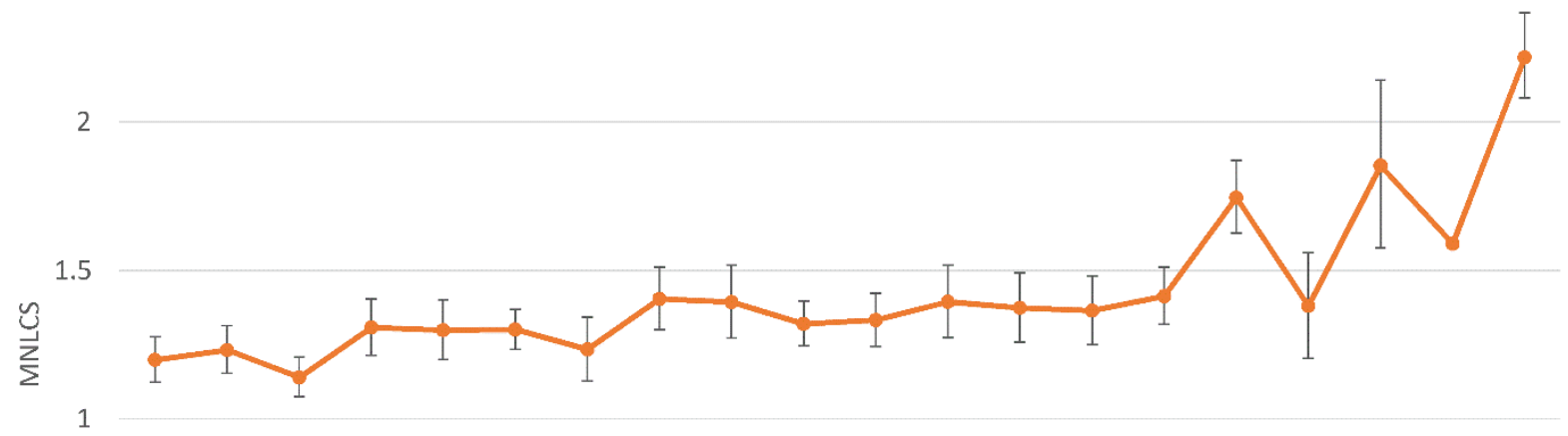

0.5

0

\begin{tabular}{|c|c|c|c|c|c|c|c|c|c|}
\hline 1996 & 1998 & 2000 & 2002 & 2004 & 2006 & 2008 & 2010 & 2012 & 2014 \\
\hline
\end{tabular}

Figure 1. MNLCS values for articles referenced by AHFS DI Essentials in the Journal of Clinical Oncology by year, together with 95\% confidence intervals. Values above 1 indicate citation impact that is above the world average for the journal.

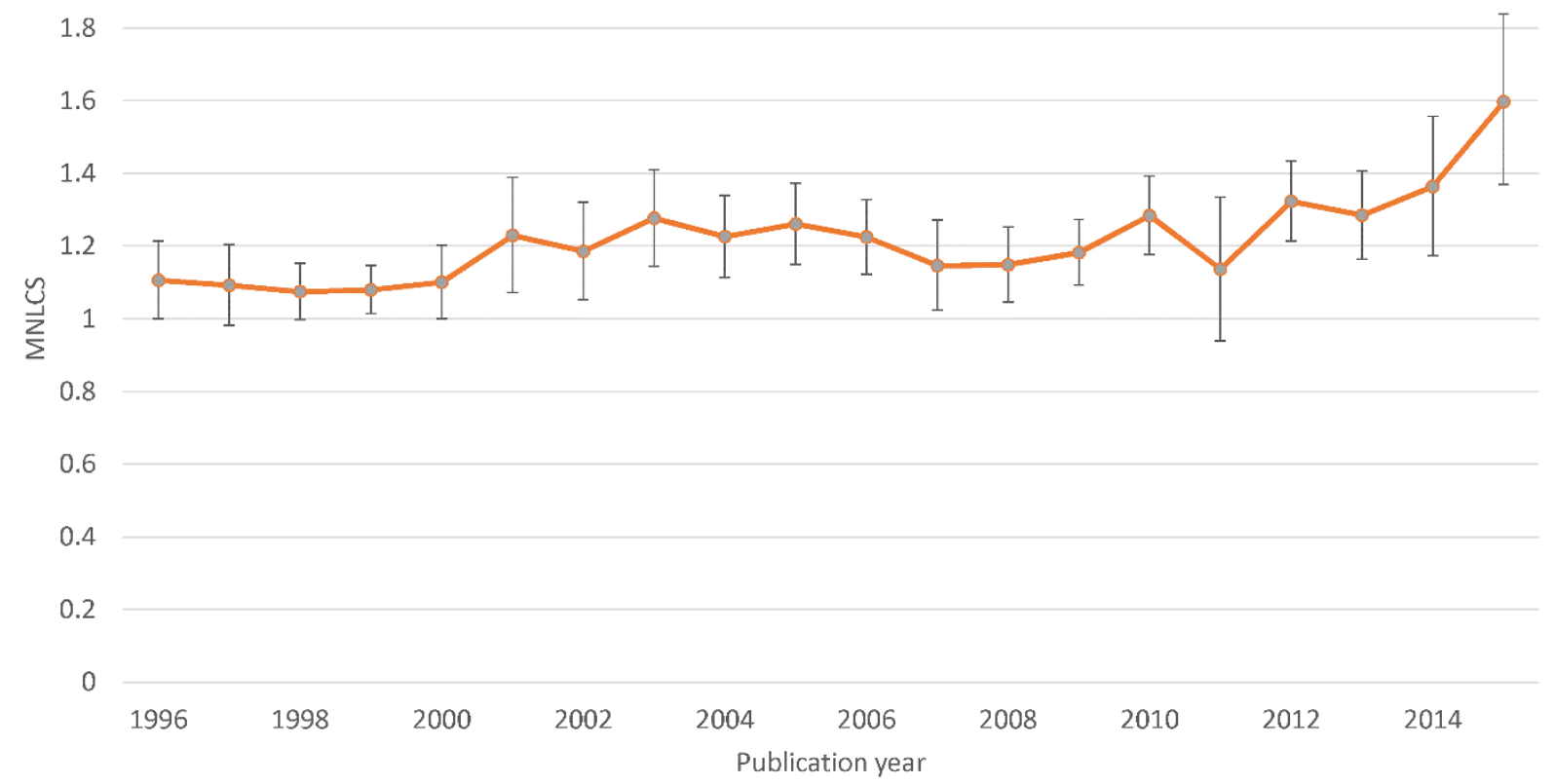

Figure 2. MNLCS values for articles referenced by AHFS DI Essentials in the Antimicrobial Agents \& Chemotherapy by year, together with 95\% confidence intervals. Values above 1 indicate citation impact that is above the world average for the journal.

\section{Discussion}

There are different possible reasons why articles referenced in AHFS DI Essentials tend to be more cited than average for the publishing general or specialist journal. For nine of the eleven examined journals, the reason is at least partly technical: submissions other than articles are classified as articles within Scopus, deflating the average citation count of all articles for the journal and therefore inflating the normalised citation count of genuine 
articles. A similar phenomenon has previously been observed for entire Scopus categories, with publications in trade journals classified as academic articles (Thelwall, 2016b).

For at least two journals in which articles referenced in AHFS DI Essentials are genuinely more highly cited than average, there are several possible explanations. Drugspecific research may be more citable than other medical research. This would explain the higher citation rates for general medical journals but not for specialist journals like Antimicrobial Agents \& Chemotherapy (and Drugs). A second possibility is that being mentioned by AHFS DI Essentials gives an article publicity and helps it to generate additional citations. Conversely, more highly cited articles may be more likely to be selected by AHFS DI Essentials since they are more well-known for practical clinical studies. Both of these seem likely to be true to some extent. Unfortunately, it is not possible to separate these awareness reasons from the possibility that AHFS DI Essentials references are more useful than typical articles from the publishing journal.

The higher citation rates of AHFS DI Essentials references is unsurprising given similar evidence from a source of clinical guidelines (Thelwall \& Maflahi, 2016) and clinical trials (Thelwall \& Kousha, 2016). Since basic medical research seems to be more citable than clinical research (Narin, Pinski, \& Gee, 1976) it may be that successful applied (clinical) research tends to be more highly cited than average in medicine. This may occur, for example, because research with practical medical applications (e.g., identifying side-effects or the effects of drugs on breastfeeding or pregnancy) is likely to trigger replication studies as well as follow-up research to check the findings in other contexts, for other diseases and with combinations of drugs. Moreover, other researchers may be inspired to take a similar approach to tackle a related problem. In contrast, it seems possible that more applied research in other areas tends to lead to a specific useful product or idea that is put into practice (e.g., in education) without generating follow-up research.

The apparent trend for higher MNLCS values for more recent years (Figures 1 and 2) does not have a clear explanation. Perhaps the most recent additions to AHFS DI Essentials references tend to be articles that more obviously have higher value than articles that have become accepted after a longer period of time.

A limitation of this study is that citations in drug guides should not be taken as definitive evidence of applied medical research value. Even official government sources can use incorrect inadequate references and in any case may (and probably should) reference high quality systematic reviews, when available, instead of primary sources (Jefferson, Di Pietrantonj, Debalini, Rivetti, \& Demicheli, 2009a). Moreover, although references in drug guides seem intuitively likely to have informed the advice, no study has definitively proven this and the choice of references may be influenced by national and other biases. Another limitation is that not all articles not cited by AHFS were checked for accurate Scopus classifications as articles. This would be time consuming to do and so only one year was checked (2015 in Antimicrobial Agents \& Chemotherapy - see above) to confirm that not all of the results could be the result of misclassifications (or differing paper lengths).

\section{Conclusions}

The methods show that it is practical to extract AHFS DI Essentials references as evidence of the applied value of medical research. Since these articles tend to be more highly cited than average for the publishing journal, their extra value may already be recognised by their traditional academic citations, however. Thus, researchers that are concerned with their 
own citation counts should not be discouraged from attempting to run useful clinical studies.

For individual researchers, an additional practical use of AHFS DI Essentials references is to support a clinical impact (e.g., informing practice, side-effects). At the time of writing, the simplest way to identify such references would be to run a site-specific Google search for the author's last name of the form [name] site:drugs.com/monograph, such as Anakwenze site:drugs.com/monograph. For systematically gathering information for research evaluation exercises then the crawling methods discussed above can be used.

A corollary to the analysis in this study is that those using field normalised citation counts from Scopus for medical areas are likely to get inflated values due to the misclassification of non-articles as articles. This is likely to have affected the UK REF2014, for example.

\section{References}

Archambault, É., Campbell, D., Gingras, Y., \& Larivière, V. (2009). Comparing bibliometric statistics obtained from the Web of Science and Scopus. Journal of the American Society for Information Science and Technology, 60(7), 1320-1326.

Barbic, D., Tubman, M., Lam, H., \& Barbic, S. (2016). An analysis of altmetrics in emergency medicine. Academic Emergency Medicine, 23(3), 251-265.

Curry, S. (2012). Eyes on the prize are blind to reality. Occam's Typewriter. http://occamstypewriter.org/scurry/2012/04/22/eyes-on-the-prize-are-blind-toreality/

de Solla Price, D. (1976). A general theory of bibliometric and other cumulative advantage processes. Journal of the American society for Information science, 27(5), 292-306.

Feder, M. E., \& Madara, J. L. (2008). Evidence-based appointment and promotion of academic faculty at the University of Chicago. Academic Medicine, 83(1), 85-95.

Fieller, E.C. (1954). Some problems in interval estimation. Journal of the Royal Statistical Society Series B, 16(2), 175-185.

Goldacre, B. (2009). Funding and findings: the impact factor. https://www.theguardian.com/commentisfree/2009/feb/14/bad-science-medicalresearch

Grant, J. (1999). Evaluating the outcomes of biomedical research on healthcare. Research Evaluation, 8(1), 33-38.

Grant, J., Cottrell, R., Cluzeau, F., \& Fawcett, G. (2000). Evaluating "payback" on biomedical research from papers cited in clinical guidelines: applied bibliometric study. Bmj, 320(7242), 1107-1111.

Hutchins, B.I., Yuan, X., Anderson, J.M., Santangelo, G.M. (2016). Relative Citation Ratio (RCR): A new metric that uses citation rates to measure influence at the article level. PLoS Biology 14(9): e1002541. doi:10.1371/journal.pbio.1002541

Jefferson, T., Di Pietrantonj, C., Debalini, M. G., Rivetti, A., \& Demicheli, V. (2009a). Inactivated influenza vaccines: methods, policies, and politics. Journal of Clinical Epidemiology, 62(7), 677-686.

Jefferson, T., Di Pietrantonj, C., Debalini, M. G., Rivetti, A., \& Demicheli, V. (2009b). Relation of study quality, concordance, take home message, funding, and impact in studies of influenza vaccines: systematic review. BMJ, 338, b354. 
Kostoff, R. N. (1998). The use and misuse of citation analysis in research evaluation. Scientometrics, 43(1), 27-43.

Kryl, D., Allen, L., Dolby, K., Sherbon, B., \& Viney, I. (2012). Tracking the impact of research on policy and practice: investigating the feasibility of using citations in clinical guidelines for research evaluation. BMJ Open, 2(2), e000897.

Lewison, G., \& Dawson, G. (1998). The effect of funding on the outputs of biomedical research. Scientometrics, 41(1-2), 17-27.

Lewison, G., \& Sullivan, R. (2008). The impact of cancer research: how publications influence UK cancer clinical guidelines. British Journal of Cancer, 98(12), 1944-1950.

Moed, H. F., \& Visser, M. S. (2008). Appraisal of citation data sources. Centre for Science and Technology Studies, Leiden University. Retrieved November 29, 2014, from http://www.hefce.ac.uk/media/hefce/content/pubs/indirreports/2008/missing/Appra isal\%20of\%20Citation\%20Data\%20Sources.pdf.

Narin, F., Pinski, G., \& Gee, H. H. (1976). Structure of the biomedical literature. Journal of the American Society for Information Science, 27(1), 25-45.

Priem, J., Taraborelli, D., Groth, P., \& Neylon, C. (2010). Altmetrics: A manifesto. http://altmetrics.org/manifesto/

Scarlat, M. M., Mavrogenis, A. F., Pećina, M., \& Niculescu, M. (2015). Impact and alternative metrics for medical publishing: Our experience with international orthopaedics. International Orthopaedics, 39(8), 1459-1464.

Schekman, R., \& Patterson, M. (2013). Reforming research assessment. Elife, 2, e00855.

Small, H., Sweeney, E., \& Greenlee, E. (1985). Clustering the Science Citation Index using cocitations. II. Mapping science. Scientometrics, 8(5-6), 321-340.

Thelwall, M. \& Kousha, K. (2016). Are citations from clinical trials evidence of higher impact research? An analysis of ClinicalTrials.gov. Scientometrics, 109(2), 1341-1351. doi:10.1007/s11192-016-2112-1

Thelwall, M. \& Maflahi, N. (2016). Guideline references and academic citations as evidence of the clinical value of health research. Journal of the Association for Information Science and Technology, 67(4), 960-966. doi:10.1002/asi.23432

Thelwall, M. \& Stuart, D. (2006). Web crawling ethics revisited: Cost, privacy and denial of service. Journal of the American Society for Information Science and Technology, 57(13), 1771-1779.

Thelwall, M. (2016a). Citation count distributions for large monodisciplinary journals. Journal of Informetrics, 10(3), 863-874. doi:10.1016/j.joi.2016.07.006

Thelwall, M. (2016b). Are there too many uncited articles? Zero inflated variants of the discretised lognormal and hooked power law distributions. Journal of Informetrics, 10(2), 622-633. doi:10.1016/j.joi.2016.04.014

Thelwall, M. (2017). Web indicators for research evaluation: A practical guide. San Rafael, CA: Morgan \& Claypool.

Thelwall, M. (in press). Three practical field normalised alternative indicator formulae for research evaluation. Journal of Informetrics. 10.1016/j.joi.2016.12.002

Waltman, L., van Eck, N. J., van Leeuwen, T. N., Visser, M. S., \& van Raan, A. F. (2011a). Towards a new crown indicator: Some theoretical considerations. Journal of Informetrics, 5(1), 37-47.

Waltman, L., van Eck, N. J., van Leeuwen, T. N., Visser, M. S., \& van Raan, A. F. (2011b). Towards a new crown indicator: An empirical analysis. Scientometrics, 87(3), 467-481. 
Wilsdon, J., Allen, L., Belfiore, E., Campbell, P., Curry, S., Hill, S., et al. (2015). The metric tide: Report of the independent review of the role of metrics in research assessment and management.

http://www.hefce.ac.uk/pubs/rereports/Year/2015/metrictide/Title,104463,en.html

\section{Appendix}

This appendix includes article types for articles cited in AHFS DI Essentials but with low Scopus citation counts, relative to the field and year of publication. Each table reports one of the seven journals not discussed in the main body of the article (Tables A1-A7).

Table A1. All articles referenced by AHFS DI Essentials but attracting fewer citations than average for New England Journal of Medicine.

\begin{tabular}{|l|r|r|l|l|}
\hline Year & $\begin{array}{l}\text { Scopus } \\
\text { citations }\end{array}$ & $\begin{array}{l}\text { Norm. } \\
\text { cit. }\end{array}$ & Article & $\begin{array}{l}\text { Type in } \\
\text { journal } \\
\text { website }\end{array}$ \\
\hline 2008 & 35 & 0.75 & Urinary stress incontinence in women & $\begin{array}{l}\text { Clinical } \\
\text { Practice }\end{array}$ \\
\hline 2009 & 50 & 0.83 & Activated protein C for sepsis & $\begin{array}{l}\text { Clinical } \\
\text { therapeutics }\end{array}$ \\
\hline 2012 & 35 & 0.84 & $\begin{array}{l}\text { Topical 0.5\% ivermectin lotion for treatment of head } \\
\text { lice }\end{array}$ & Article \\
\hline 2005 & 66 & 0.87 & Acne & $\begin{array}{l}\text { Clinical } \\
\text { Practice }\end{array}$ \\
\hline 2002 & 84 & 0.88 & Head lice & $\begin{array}{l}\text { Clinical } \\
\text { Practice }\end{array}$ \\
\hline 2009 & 66 & 0.89 & Fungal nail disease & $\begin{array}{l}\text { Clinical } \\
\text { Practice }\end{array}$ \\
\hline 2006 & 79 & 0.93 & $\begin{array}{l}\text { Single-dose azithromycin for the treatment of } \\
\text { cholera in adults }\end{array}$ & Article \\
\hline 2009 & 82 & 0.93 & $\begin{array}{l}\text { Antivenom for critically ill children with } \\
\text { neurotoxicity from scorpion stings }\end{array}$ & Article \\
\hline 2002 & 131 & 0.97 & $\begin{array}{l}\text { Tissue plasminogen activator in cardiac arrest with } \\
\text { pulseless electrical activity }\end{array}$ & Article \\
\hline 1997 & 43 & 0.97 & $\begin{array}{l}\text { Cost effectiveness of oral as compared with } \\
\text { intravenous antibiotic therapy for patients with } \\
\text { early lyme disease or lyme arthritis }\end{array}$ & $\begin{array}{l}\text { Special } \\
\text { Report }\end{array}$ \\
\hline 2010 & 85 & 0.98 & Retinal-vein occlusion & $\begin{array}{l}\text { Clinical } \\
\text { Practice }\end{array}$ \\
\hline 2003 & 165 & 1.00 & Prolactinoma & $\begin{array}{l}\text { Clinical } \\
\text { Practice }\end{array}$ \\
\hline
\end{tabular}

The specialist journal Circulation has classification problems because some (three) of the articles in this journal are not standard journal articles. Several have the now discontinued subtype, Clinical Investigation and Reports, which probably equivalent to a traditional journal article (Table A2). Similar classification errors also occurred in some of the remaining articles in this journal. 
Table A2. All articles referenced by AHFS DI Essentials but attracting fewer citations than average for Circulation.

\begin{tabular}{|c|c|c|c|c|}
\hline Year & $\begin{array}{l}\text { Scopus } \\
\text { citations }\end{array}$ & $\begin{array}{l}\text { Norm. } \\
\text { cit. }\end{array}$ & Article & $\begin{array}{l}\text { Type in journal } \\
\text { website }\end{array}$ \\
\hline 2012 & 13 & 0.76 & $\begin{array}{l}\text { Guided antithrombotic therapy: Current } \\
\text { status and future research direction: Report } \\
\text { on a national heart, lung and blood institute } \\
\text { working group }\end{array}$ & Special Report \\
\hline 2001 & 41 & 0.83 & $\begin{array}{l}\text { Prognostic significance of thrombocytopenia } \\
\text { during hirudin and heparin therapy in acute } \\
\text { coronary syndrome without ST elevation: } \\
\text { Organization to assess strategies for } \\
\text { ischemic syndromes (OASIS-2) study }\end{array}$ & $\begin{array}{l}\text { Clinical } \\
\text { Investigation and } \\
\text { Reports }\end{array}$ \\
\hline 2000 & 44 & 0.86 & $\begin{array}{l}\text { Survival outcomes } 1 \text { year after reperfusion } \\
\text { therapy with either alteplase or reteplase for } \\
\text { acute myocardial infarction: Results from the } \\
\text { global utilization of streptokinase and t-PA } \\
\text { for occluded coronary arteries (GUSTO) III } \\
\text { trial }\end{array}$ & $\begin{array}{l}\text { Clinical } \\
\text { Investigation and } \\
\text { Reports }\end{array}$ \\
\hline 2005 & 51 & 0.88 & $\begin{array}{l}\text { The use of nonsteroidal anti-inflammatory } \\
\text { drugs (NSAIDs): A Science Advisory from the } \\
\text { American Heart Association }\end{array}$ & $\begin{array}{l}\text { AHA Science } \\
\text { Advisory }\end{array}$ \\
\hline 1999 & 57 & 0.92 & $\begin{array}{l}\text { Stroke in patients with acute coronary } \\
\text { syndromes: Incidence and outcomes in the } \\
\text { platelet glycoprotein Ilb/Illa in unstable } \\
\text { angina: Receptor suppression using integrilin } \\
\text { therapy (PURSUIT) trial }\end{array}$ & $\begin{array}{l}\text { Clinical } \\
\text { Investigation and } \\
\text { Reports }\end{array}$ \\
\hline 2003 & 85 & 0.98 & $\begin{array}{l}\text { The use of nonsteroidal anti-inflammatory } \\
\text { drugs (NSAIDs): A Science Advisory from the } \\
\text { American Heart Association }\end{array}$ & $\begin{array}{l}\text { AHA Scientific } \\
\text { Statements }\end{array}$ \\
\hline
\end{tabular}


Table A3. All articles referenced by AHFS DI Essentials but attracting fewer citations than average for $B M J$.

\begin{tabular}{|l|r|r|l|l|}
\hline Year & $\begin{array}{l}\text { Scopus } \\
\text { citations }\end{array}$ & $\begin{array}{l}\text { Norm. } \\
\text { cit. }\end{array}$ & Article & $\begin{array}{l}\text { Type in } \\
\text { journal } \\
\text { website }\end{array}$ \\
\hline 1999 & 3 & 0.35 & $\begin{array}{l}\text { Drug points: Fatal erythroderma associated with } \\
\text { pentostatin }\end{array}$ & Article \\
\hline 1996 & 18 & 0.77 & $\begin{array}{l}\text { Addison's disease presenting as reduced insulin } \\
\text { requirement in insulin dependent diabetes }\end{array}$ & $\begin{array}{l}\text { Education } \\
\text { and } \\
\text { Debate }\end{array}$ \\
\hline 1997 & 23 & 0.81 & $\begin{array}{l}\text { Sneumococcal polysaccharide vaccine in patients with } \\
\text { chronic respiratory disease }\end{array}$ & Article \\
\hline 2002 & 28 & 0.81 & $\begin{array}{l}\text { Metabolic decompensation in pump users due to lispro } \\
\text { insulin precipitation }\end{array}$ & Article \\
\hline 2001 & 35 & 0.87 & $\begin{array}{l}\text { Drug points: Cholestatic hepatitis in association with } \\
\text { celecoxib }\end{array}$ & Article \\
\hline 2008 & 29 & 0.88 & $\begin{array}{l}\text { Hypersensitivity reactions to human papillomavirus } \\
\text { vaccine in Australian schoolgirls: Retrospective cohort } \\
\text { study }\end{array}$ & $\begin{array}{l}\text { Acute angle closure glaucoma associated with } \\
\text { paroxetine }\end{array}$ \\
\hline 1997 & 38 & 0.93 & & Article \\
\hline
\end{tabular}


Table A4. Top 20 articles referenced by AHFS DI Essentials but attracting fewer citations than average for Clinical Infectious Diseases.

\begin{tabular}{|c|c|c|c|c|}
\hline Year & $\begin{array}{l}\text { Scopus } \\
\text { citations }\end{array}$ & $\begin{array}{l}\text { Norm. } \\
\text { cit. }\end{array}$ & Article & $\begin{array}{l}\text { Type in journal } \\
\text { website }\end{array}$ \\
\hline 1996 & 2 & 0.37 & $\begin{array}{l}\text { Early initiation of antiretroviral therapy for infection } \\
\text { with human immunodeficiency virus: Considerations } \\
\text { in } 1996\end{array}$ & Article \\
\hline 2009 & 3 & 0.38 & $\begin{array}{l}\text { Outcomes among inmates treated for } \\
\text { coccidioidomycosis at a correctional institution during } \\
\text { a community outbreak, kern county, California, } 2004\end{array}$ & Article \\
\hline 1997 & 5 & 0.56 & $\begin{array}{l}\text { Measurement of human immunodeficiency virus } \\
\text { (HIV) type } 1 \text { RNA load distinguishes progressive } \\
\text { infection from nonprogressive HIV-1 infection in men } \\
\text { and women }\end{array}$ & Brief report \\
\hline 1997 & 5 & 0.56 & Cerebral relapse of sarcoidlike Whipple's disease & Article \\
\hline 1998 & 8 & 0.69 & $\begin{array}{l}\text { Anaphylaxis upon switching lipid-containing } \\
\text { amphotericin B formulations }\end{array}$ & Brief report \\
\hline 1996 & 7 & 0.69 & $\begin{array}{l}\text { Fluconazole-resistant Candida parapsilosis fungemia } \\
\text { in a patient with AIDS }\end{array}$ & Brief report \\
\hline 1997 & 9 & 0.72 & $\begin{array}{l}\text { Cardiac arrhythmias associated with coadministration } \\
\text { of azole compounds and cisapride [4] (multiple } \\
\text { letters) }\end{array}$ & Correspondence \\
\hline 1999 & 10 & 0.75 & $\begin{array}{l}\text { Hydroxyurea toxicity in human immunodeficiency } \\
\text { virus-positive patients }\end{array}$ & Brief report \\
\hline 2009 & 15 & 0.76 & Cefepime therapy and all-cause mortality & View point \\
\hline 1997 & 11 & 0.78 & $\begin{array}{l}\text { Recurrent iritis after intravenous administration of } \\
\text { cidofovir }\end{array}$ & Brief report \\
\hline 2000 & 17 & 0.81 & $\begin{array}{l}\text { Rhodococcus equi nosocomial meningitis cured by } \\
\text { levofloxacin and shunt removal }\end{array}$ & Brief report \\
\hline 1999 & 13 & 0.82 & $\begin{array}{l}\text { Hydroxyurea-induced hepatitis in human } \\
\text { immunodeficiency virus-positive patients }\end{array}$ & Brief report \\
\hline 1999 & 13 & 0.82 & $\begin{array}{l}\text { Primary lamivudine resistance in acute/early human } \\
\text { immunodeficiency virus infection }\end{array}$ & Brief report \\
\hline 2001 & 20 & 0.85 & $\begin{array}{l}\text { Failure of treatment for chronic Mycobacterium } \\
\text { abscessus meningitis despite adequate clarithromycin } \\
\text { levels in cerebrospinal fluid }\end{array}$ & Brief report \\
\hline 1997 & 15 & 0.87 & $\begin{array}{l}\text { A fluconazole/amitriptyline drug interaction in three } \\
\text { male adults }\end{array}$ & Brief report \\
\hline 2001 & 22 & 0.88 & $\begin{array}{l}\text { Cerebrospinal fluid penetration of levofloxacin in } \\
\text { patients with spontaneous acute bacterial meningitis }\end{array}$ & Brief report \\
\hline 2010 & 19 & 0.89 & $\begin{array}{l}\text { Two cases of daptomycin-induced eosinophilic } \\
\text { pneumonia and chronic pneumonitis }\end{array}$ & Brief report \\
\hline 1998 & 17 & 0.91 & $\begin{array}{l}\text { Successful treatment of primary Actinomyces viscosus } \\
\text { endocarditis with third-generation cephalosporins }\end{array}$ & Brief report \\
\hline 2001 & 25 & 0.91 & $\begin{array}{l}\text { Ivermectin treatment of a traveler who returned from } \\
\text { Peru with cutaneous gnathostomiasis. }\end{array}$ & Brief report \\
\hline 2000 & 25 & 0.92 & $\begin{array}{l}\text { Cerebrospinal fluid penetration of high doses of } \\
\text { intravenous ciprofloxacin in meningitis }\end{array}$ & Article \\
\hline
\end{tabular}


Table A5. All articles referenced by AHFS DI Essentials but attracting fewer citations than average for Archives of Internal Medicine/JAMA Internal Medicine.

\begin{tabular}{|c|c|c|c|c|}
\hline Year & $\begin{array}{l}\text { Scopus } \\
\text { citations }\end{array}$ & $\begin{array}{l}\text { Norm. } \\
\text { cit. }\end{array}$ & Article & $\begin{array}{l}\text { Type in } \\
\text { journal } \\
\text { website }\end{array}$ \\
\hline 2001 & 6 & 0.48 & $\begin{array}{l}\text { A randomized Multicenter Trial of Crotalinae polyvalent } \\
\text { immune Fab (ovine) antivenom for the treatment for } \\
\text { crotaline snakebite in the United States }\end{array}$ & Article \\
\hline 1998 & 22 & 0.76 & A drug interaction between zafirlukast and theophylline & $\begin{array}{l}\text { Clinical } \\
\text { Observation }\end{array}$ \\
\hline 1997 & 24 & 0.79 & $\begin{array}{l}\text { Fluconazole as prophylaxis against fungal infection in } \\
\text { patients with advanced HIV infection }\end{array}$ & Article \\
\hline 1996 & 25 & 0.81 & Severe hyponatremia during therapy with fluoxetine & Article \\
\hline 2005 & 36 & 0.82 & $\begin{array}{l}\text { Bortezomib-induced severe hepatitis in multiple } \\
\text { myeloma: A case report }\end{array}$ & $\begin{array}{l}\text { Clinical } \\
\text { Observation }\end{array}$ \\
\hline 1996 & 28 & 0.84 & $\begin{array}{l}\text { Clinical ergotism with lingual ischemia induced by } \\
\text { clarithromycin-ergotamine interaction }\end{array}$ & Article \\
\hline 2005 & 57 & 0.93 & $\begin{array}{l}\text { Selective cyclooxygenase- } 2 \text { inhibition and cardiovascular } \\
\text { effects: An observational study of a medicaid population }\end{array}$ & Article \\
\hline 2000 & 64 & 0.94 & $\begin{array}{l}\text { Safety and efficacy of meloxicam in the treatment of } \\
\text { osteoarthritis: A } 12 \text {-week, double-blind, multiple-dose, } \\
\text { placebo-controlled trial }\end{array}$ & Article \\
\hline
\end{tabular}

Table A6. All articles referenced by AHFS DI Essentials but attracting fewer citations than average for Pediatrics.

\begin{tabular}{|l|r|r|l|l|}
\hline Year & $\begin{array}{l}\text { Scopus } \\
\text { citations }\end{array}$ & $\begin{array}{l}\text { Norm. } \\
\text { cit. }\end{array}$ & Article & $\begin{array}{l}\text { Type in } \\
\text { journal } \\
\text { website }\end{array}$ \\
\hline 1996 & 22 & 0.84 & $\begin{array}{l}\text { Clinical and pathologic aspects of cardiomyopathy from } \\
\text { ipecac administration in Munchausen's syndrome by } \\
\text { proxy }\end{array}$ & Article \\
\hline 1996 & 32 & 0.94 & $\begin{array}{l}\text { Combination therapy with stavudine and didanosine in } \\
\text { children with advanced human immunodeficiency virus } \\
\text { infection: Pharmacokinetic properties, safety, and } \\
\text { immunologic and virologic effects }\end{array}$ & Article \\
\hline 1996 & 35 & 0.96 & Use of diet history in the screening of iron deficiency & Article \\
\hline 1996 & 38 & 0.98 & $\begin{array}{l}\text { Recurrent thrombocytopenic purpura after repeated } \\
\text { measles-mumps-rubella vaccination }\end{array}$ & $\begin{array}{l}\text { Experience } \\
\text { and } \\
\text { Reason }\end{array}$ \\
\hline 1996 & 40 & 0.99 & $\begin{array}{l}\text { Methylene blue-induced phototoxicity: An unrecognized } \\
\text { complication }\end{array}$ & Article \\
\hline 1997 & 44 & 0.99 & $\begin{array}{l}\text { Needle length and injection technique for efficient } \\
\text { intramuscular vaccine delivery in infants and children } \\
\text { evaluated through an ultrasonographic determination of } \\
\text { subcutaneous and muscle layer thickness }\end{array}$ & $\begin{array}{l}\text { Experience } \\
\text { and } \\
\text { Reason }\end{array}$ \\
\hline 1999 & 15 & 0.71 & $\begin{array}{l}\text { Assessment of medical personnel exposure to nitrogen } \\
\text { oxides during inhaled nitric oxide treatment of neonatal } \\
\text { and pediatric patients }\end{array}$ & Article \\
\hline 1999 & 34 & 0.91 & $\begin{array}{l}\text { Thalidomide responsiveness in an infant with Behcet's } \\
\text { syndrome }\end{array}$ & $\begin{array}{l}\text { Experience } \\
\text { and }\end{array}$ \\
\hline
\end{tabular}




\begin{tabular}{|c|c|c|c|c|}
\hline & & & & Reason \\
\hline 1999 & 40 & 0.95 & $\begin{array}{l}\text { Prevention of poliomyelitis: Recommendations for use } \\
\text { of only inactivated poliovirus vaccine for routine } \\
\text { immunization }\end{array}$ & Guideline \\
\hline 2000 & 15 & 0.69 & $\begin{array}{l}\text { Fomepizole treatment of ethylene glycol poisoning in an } \\
\text { infant }\end{array}$ & $\begin{array}{l}\text { Case } \\
\text { Report }\end{array}$ \\
\hline 2001 & 30 & 0.83 & $\begin{array}{l}\text { Severe ethylene glycol ingestion treated without } \\
\text { hemodialysis }\end{array}$ & $\begin{array}{l}\text { Case } \\
\text { Reports }\end{array}$ \\
\hline 2001 & 61 & 1.00 & $\begin{array}{l}\text { Insulin lispro lowers postprandial glucose in prepubertal } \\
\text { children with diabetes }\end{array}$ & Article \\
\hline 2002 & 21 & 0.74 & $\begin{array}{l}\text { Interchangeability of } 2 \text { diphtheria-tetanus-acellular } \\
\text { pertussis vaccines in infancy }\end{array}$ & $\begin{array}{l}\text { Clinical } \\
\text { Trial }\end{array}$ \\
\hline 2002 & 45 & 0.92 & $\begin{array}{l}\text { Crotaline Fab antivenom for the treatment of children } \\
\text { with rattlesnake envenomation }\end{array}$ & Article \\
\hline 2002 & 53 & 0.96 & $\begin{array}{l}\text { Terbinafine in the treatment of Trichophyton tinea } \\
\text { capitis: A randomized, double-blind, parallel-group, } \\
\text { duration-finding study }\end{array}$ & Article \\
\hline 2004 & 19 & 0.74 & $\begin{array}{l}\text { Risk Factors for Emesis after Therapeutic Use of } \\
\text { Activated Charcoal in Acutely Poisoned Children }\end{array}$ & Article \\
\hline 2007 & 33 & 0.97 & $\begin{array}{l}\text { Infant botulism: A 30-year experience spanning the } \\
\text { introduction of botulism immune globulin intravenous in } \\
\text { the intensive care unit at Childrens Hospital Los Angeles }\end{array}$ & Article \\
\hline 2008 & 24 & 0.87 & $\begin{array}{l}\text { Coadministration of RIX4414 oral human rotavirus } \\
\text { vaccine does not impact the immune response to } \\
\text { antigens contained in routine infant vaccines in the } \\
\text { united states }\end{array}$ & Article \\
\hline 2008 & 26 & 0.89 & $\begin{array}{l}\text { Safety and immunogenicity of concureent } \\
\text { administration of live attenuated influenza vaccine with } \\
\text { measles-mumps-rubella and varicella vaccines to infants } \\
12 \text { to } 15 \text { months of age }\end{array}$ & Article \\
\hline
\end{tabular}


Table A7. All articles referenced by AHFS DI Essentials but attracting fewer citations than average for Drugs.

\begin{tabular}{|c|c|c|c|c|}
\hline Year & $\begin{array}{l}\text { Scopus } \\
\text { citations }\end{array}$ & $\begin{array}{l}\text { Norm. } \\
\text { cit. }\end{array}$ & Article & $\begin{array}{l}\text { Type in } \\
\text { journal } \\
\text { website }\end{array}$ \\
\hline 1997 & 6 & 0.58 & $\begin{array}{l}\text { Ancillary benefits of Mycobacterium avium- } \\
\text { intracellulare complex prophylaxis with } \\
\text { clarithromycin in HIV-infected patients }\end{array}$ & Article \\
\hline 2014 & 3 & 0.59 & Suvorexant: First global approval & Article \\
\hline 2013 & 4 & 0.62 & $\begin{array}{l}\text { Crofelemer: A review of its use in the management } \\
\text { of non-infectious diarrhoea in adult patients with } \\
\text { HIV/AIDS on antiretroviral therapy }\end{array}$ & Article \\
\hline 2012 & 5 & 0.68 & Aclidinium: In chronic obstructive pulmonary disease & $\begin{array}{l}\text { Adis Drug } \\
\text { Profile }\end{array}$ \\
\hline 2015 & 2 & 0.69 & Evolocumab: First Global Approval & $\begin{array}{l}\text { Adis Insight } \\
\text { Report }\end{array}$ \\
\hline 1999 & 15 & 0.79 & $\begin{array}{l}\text { Isosorbide 5-mononitrate. A review of a sustained- } \\
\text { release formulation }\left(\text { Imdur }^{\circledR}\right) \text { in stable angina } \\
\text { pectoris }\end{array}$ & $\begin{array}{l}\text { Adis Drug } \\
\text { Evaluation }\end{array}$ \\
\hline 1998 & 19 & 0.83 & $\begin{array}{l}\text { Recent antiplatelet drug trials in the acute coronary } \\
\text { syndromes. Clinical interpretation of PRISM, PRISM- } \\
\text { PLUS, PARAGON A and PURSUIT }\end{array}$ & $\begin{array}{l}\text { Leading } \\
\text { Article }\end{array}$ \\
\hline 1999 & 18 & 0.84 & $\begin{array}{l}\text { Clinical efficacy of metformin against insulin } \\
\text { resistance parameters sinking the iceberg }\end{array}$ & $\begin{array}{l}\text { Review } \\
\text { Article }\end{array}$ \\
\hline 2001 & 24 & 0.85 & Fulvestrant & $\begin{array}{l}\text { Adis New } \\
\text { Drug Profile }\end{array}$ \\
\hline 1998 & 22 & 0.87 & $\begin{array}{l}\text { Topotecan: A review of its potential in advanced } \\
\text { ovarian cancer }\end{array}$ & $\begin{array}{l}\text { Adis Drug } \\
\text { Evaluation }\end{array}$ \\
\hline 1996 & 19 & 0.87 & $\begin{array}{l}\text { Pharmacological Treatment of Psychiatric Disorders } \\
\text { in Children and Adolescents: Focus on Guidelines for } \\
\text { the Primary Care Practitioner }\end{array}$ & Article \\
\hline 2015 & 3 & 0.88 & Alirocumab: First Global Approval & $\begin{array}{l}\text { Adis Insight } \\
\text { Report }\end{array}$ \\
\hline 2014 & 7 & 0.89 & Vorapaxar: First global approval & $\begin{array}{l}\text { R\&D Insight } \\
\text { Report }\end{array}$ \\
\hline 2001 & 28 & 0.89 & Thalidomide in gastrointestinal disorders & $\begin{array}{l}\text { Therapy in } \\
\text { Practice }\end{array}$ \\
\hline 1996 & 22 & 0.91 & Head and Neck Cancer: Guidelines for Chemotherapy & $\begin{array}{l}\text { Disease } \\
\text { Management }\end{array}$ \\
\hline 1997 & 24 & 0.96 & $\begin{array}{l}\text { Current recommendations for the management of } \\
\text { bladder cancer: Drug therapy }\end{array}$ & $\begin{array}{l}\text { Disease } \\
\text { Management }\end{array}$ \\
\hline 2001 & 40 & 0.98 & Desloratadine & $\begin{array}{l}\text { Adis New } \\
\text { Drug Profile }\end{array}$ \\
\hline 1998 & 35 & 0.99 & Management of malignant pleural effusions & $\begin{array}{l}\text { Disease } \\
\text { Management }\end{array}$ \\
\hline
\end{tabular}

